\title{
Impact of ATM Banking Performance on Customer Satisfaction with the Bank in Malawi
}

\author{
Charles Mwatsika \\ Management Studies Department, University of Malawi, Blantyre, Malawi
}

\section{Email address:}

cmwatsika@poly.ac.mw

\section{To cite this article:}

Charles Mwatsika. Impact of ATM Banking Performance on Customer Satisfaction with the Bank in Malawi. International Journal of Business and Economics Research. Vol. 5, No. 1, 2016, pp. 1-9. doi: 10.11648/j.ijber.20160501.11

\begin{abstract}
Automated teller machine banking has become a significant channel for banking products and services behind branch banking in Malawi and banks continue to invest in new and efficient technologies that can handle more functions that include cash depositing to attract more customers and achieve customer satisfaction with the banks. 353 respondents participated in this study to assess the impact of Automated teller machine banking performance on customer satisfaction with banks. The study adopted a performance only approach to measuring customer satisfaction. A self administered questionnaire containing multi-dimension and multi-attribute Likert measurement scales was used where respondents rated the performance only and their satisfaction with Automated teller machine banking and satisfaction with their respective banks. Using SPSS, regression analysis of satisfaction with Automated teller machine banking performance and satisfaction with the bank was conducted and the results indicate that performance of automated teller machine banking has 40 percent predictive capability of customer satisfaction with the bank. The study further found that despite influencing customer satisfaction with the bank, Automated teller machine banking has no capability to attract customers to switch banks. Therefore banks could improve their customer satisfaction ratings through improvements in Automated teller machine banking services but where the banks wish to attract customers from rivals, alternative marketing strategies should be sought.
\end{abstract}

Keywords: Bank Performance, Auto Teller Machines, Customer Satisfaction

\section{Introduction}

The evolution of information and communications technology (ICT) has brought development and adoption of advanced technologies in commerce and industry. One such modern technology in the banking sector is the Automated Teller Machine (ATM) system. An ATM system is an interorganisational system that links banks and other financial institutions to retail banking customers for several types of routine banking transactions. These include inquiries, deposits, cash withdrawals, cash transfers and payments (Dos Santos and Peffers, 1993). Although ATMs were introduced in banking in America in the early 1970s (Dos Santos and Peffers, 1993), in Malawi, ATMs were introduced in early 2000. A decade later, all commercial banks in Malawi own a network of ATMs for the delivery of banking products/services.

Literature shows that ATM banking has received customer preference to become the second most popular channel for accessing banking products/services behind branch banking.
ATMs provide bank customers with 24 hour access to banking products/services; they are easy to use and are faster than human tellers in the banking halls. ATM systems are believed to have improved the operational efficiency of banks and customer service in the banking sector (Banker and Kauffman, 1988; Glaser, 1988; Laderman, 1990). Although ATM systems have high fixed costs, they have lower variable transaction processing costs according to research. With that proficiency ATMs could be substituted for employees that provide services on demand deposits accounts thereby be able to reduce the number of transactions processed by human tellers. That would allow banks to reduce direct customer service employment (Kantrow, 1989). ATMs have therefore become strategic technology in the banking sector in delivering banking products/services and are expected to offer competitive advantage to banks investing in ATM technologies over those that do not.

Today, investment in ATM technologies remains strategic as banks continue to invest in newer and more efficient ATM technologies to bolster delivery of an efficient banking 
experience. It is the goal of banks to offer competitive services and keep an expanding base of satisfied customers to remain competitive and profitable. This is evident through banks' investment drive in improving and increasing delivery channels, product/service reach and customer communication. However, although ATM systems are believed to have improved operational efficiency and customer service, the study by Banker and Kauffman (1988) did find that ATMs did not affect the banks market share. The study on the effects of early adoption of information technology by Dos Santos and Peffers (1993) found that not all early adopters of ATM technology were able to improve human resource proficiency and the study further found that in some cases early adoption of ATM banking even decreased efficiency.

The studies on adoption of ATM systems however reveal that early adoption of ATMs only increased market share in certain environments and that the competitive advantage created by early adoption of ATMs was short lived, enjoyed only until other banks adopted ATM technology. As studies on early adoption of ATM technologies have shown that competitive advantage achieved through adoption of ATMs was short lived only until other banks adopted ATM technologies, this study was set to assess the impact of ATM banking performance on customer satisfaction with banks. Now that each bank in Malawi has installed ATM technologies to deliver banking products/services, is the performance of these ATM technologies critical to customer satisfaction with their banks? Are ATMs still an area that can offer a bank competitive advantage or are they just an investment requirement in retail banking and that banks should look elsewhere to achieve competitive advantage and customer satisfaction?

Various studies have been conducted to assess customer satisfaction with ATM banking and the key attributes that influence customer satisfaction with ATMs. However, not many studies have been conducted to assess the impact of ATM banking performance on customer satisfaction with banks post early adoption.

The objective of this research therefore, was to assess the impact of ATM banking performance on customer satisfaction with their respective banks. The study's aim was to find out if the performance of ATM banking influences customer satisfaction with their banks and thereby inform bank management the relative importance of ATM banking in the pursuit of customer satisfaction and the benefits that result from its achievement.

The research is relevant to bank performance, auto teller machines and customer satisfaction.

\section{Materials and Methods}

\subsection{Research Model}

The study adopted the SERVPERF approach (Cronin and Taylor, 1992) to the measurement of customer satisfaction with ATM banking and customer satisfaction. Specific attributes of
ATM banking were adopted from empirical researches; Al Hawari et al (2006), Athanassopoulos (2000), Davies et al (1996), Howcroft (1991), Joseph and Stone (2003), Moutinho and Brownlie (1989), Patricio et al (2003), and Yavas et al (2004). 25 ATM banking attributes in total were adopted from empirical studies and were categorized into the five service quality dimensions of tangibles, reliability, responsiveness, assurance and empathy (Parasuraman, et al, 1988). Tangibles are the physical equipment, its appearance, support services and even the appearance of service personnel; reliability refers to the degree to which accurate, dependable and timely services are offered to the users; responsiveness is the ability to respond effectively and willingness of service providers to help customers and meet their needs and wants; assurance refers to the issues of confidence and trust that customers have and the feeling of safety in case of perceived problems; and empathy refers to the attention and care that service providers offer to customers which further refers to convenient operating arrangements. ATM banking was perceived to be one of the key attributes of the banks service quality delivery mechanism. The study was therefore guided by the model Figure 1 .

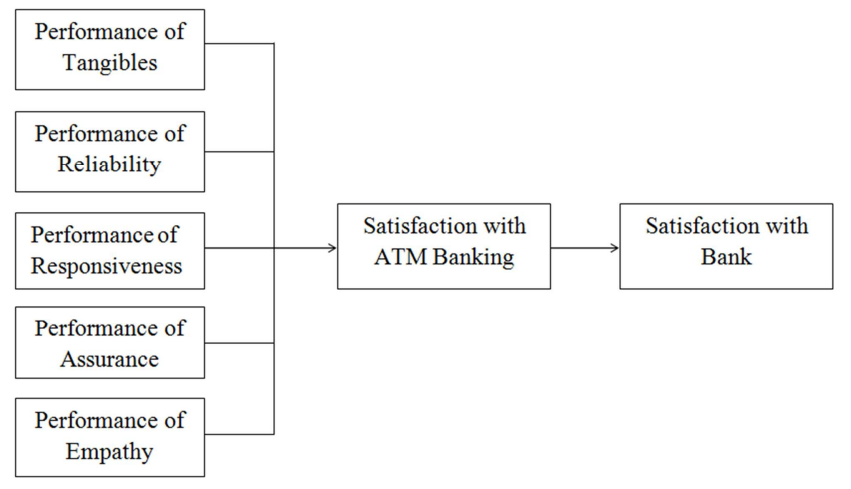

Figure 1. Research model.

The study model conceptualizes that satisfaction with ATM banking is affected by the performance of ATM banking service quality attributes under each of the five dimensions and in turn satisfaction with ATM banking would affect satisfaction with the Bank. It is based on this understanding that the research hypothesized that ATM banking performance has a positive relationship with customer satisfaction with the bank.

\subsection{Research Questionnaire}

The research questionnaire was then developed for conducting the research. The first section of the questionnaire collected demographic data of the respondents that included gender, age group, education level, name of respondent's bank, length of period with the bank, length of ATM banking experience and frequency of ATM usage. The second part of the questionnaire was the measurement scales that comprised 25 ATM banking attributes adopted from empirical studies. These included; number of ATMs per station, convenient location, corporate branding appearance on ATMs, readable slips, issuing of clean notes, cleanliness of ATMs and ATM 
stations, range of services at ATMs, accuracy of ATM transactions, speed of ATMs, ATMs not out of order, ATM system usability, ease of access to ATMs, cash availability in ATMs, quick replacement of lost ATM cards, waiting times at ATMs, fast return of swallowed ATM cards, employee speed in dealing with ATM problems, employee effectiveness in solving ATM problems, privacy at ATMs, ATM usage and security advice, security at ATM stations, employee friendliness, ATM fees, ease of ATM card application process and employee accessibility to solve ATM issues (Al Hawari et al, 2006; Athanassopoulos, 2000; Davies et al, 1996; Howcroft, 1991; Joseph and Stone, 2003; Moutinho and Brownlie, 1989; Patricio et al, 2003; and Yavas et al, 2004). The measurement of performance and satisfaction was done on a five point Likert scale where 1 was equal to 'very poor', 'very dissatisfied'; 2 was equal to 'poor', 'dissatisfied'; 3 was equal to 'neither poor nor good', 'neither dissatisfied not satisfied'; 4 was equal to 'good', 'satisfied' and 5 was equal to 'very good', 'very satisfied'. The Cronbach's alpha of 0.855 for the measurement scale demonstrated the scale's ability to provide reliable measurement with internal consistency (Nunnally and Bernstein, 1994).

The questionnaire was piloted on 30 ATM customers to assess comprehension and structure before being administered to a conveniently drawn sample of 500 bank customers. Banks customers' details are classified information to access for sampling purposes as a result the study opted for convenient sampling where 353 responses were collected representing 71 percent response rate. One questionnaire was declared unusable due to missing information leaving 352 questionnaires for analysis. Respondents rated on a five point Likert scale, their perceptions of ATM banking performance on each attribute and their satisfaction with the performance of each attribute before measuring their perceptions on satisfaction with ATM banking and satisfaction with their banks. The responses from collected questionnaires were entered into SPSS where descriptive statistical analysis and regression analysis of the performance of ATM banking and customer satisfaction were conducted.

It is important to note that the study drew responses from participants from urban areas with a very good level of education. Johnston (1995) found that the differences in education, culture, experience, exposure and tolerance levels of service quality affect participants' perceptions of satisfaction in particular contexts. These differences do apply to the sample in this study therefore the generalization and/or application of the results from this study should be taken with caution.

\section{Literature Review}

\subsection{Financial Sector}

Banks are the largest section of financial institutions in Malawi. Banks in Malawi accept deposits from individuals and/or firms and make loans to individuals and/or firms. The accepted deposits are liabilities to the banks and in turn banks use the deposits to make loans and buy government securities (assets). The deposits form the basic products/services that are provided by banks categorized as current accounts (chequeable deposits), savings accounts (un-chequeable deposits) both payable on demand and time deposits with fixed term to maturity. The loan products include consumer, commercial and mortgage loans and banks have different variations of such consumer and commercial loans.

Therefore banking is a very important aspect in modern economies as it facilitates making and receiving of payments, saving of finances for future investment, financing current consumption and supporting long term investment. Thereby expanding access to banking services to the unbanked population can stimulate the economy by mobilizing resources for long term investment support.

Bank operations in Malawi are split into retail banking which provides intermediary and payment services to individuals and small businesses and corporate banking which is more of wholesale banking to corporate large firms. Retail banking deals with large numbers of small value transactions as opposed to corporate banking and also store huge information of individual customers.

The banking industry in Malawi was dominated by two commercial banks up until the late 1990s. To date there are over ten commercial banks all of which provide the homogenous banking products/services. Branch banking had been the predominant access channel to banking products/services until the early 2000 when ATMs were introduced in the banking sector in Malawi. ATM banking has significantly grown to be the second most popular access channel to banking products/services. ATMs are installed outside banking halls, at supermarkets, service stations and many other strategic locations across the country. Other modes of accessing banking products/services in Malawi include internet banking, Point of Sales (POS) devices and mobile phone banking (m-banking). However, these other channels are at early or adoption stage. Internet banking is negatively affected by the low levels of internet penetration in the country as 50.7 percent of the population is poor and 80 percent of the poor live in rural areas and are affected by poor telecommunication and internet infrastructure for broadband services that make it expensive to access internet in Malawi. The mobile phone banking (m-banking) is another channel with high potential to penetrate the rural and peri-urban under-banked and unbanked population because of the penetration of the mobile phone in rural areas among the poor population. However, not many banks are pursuing to develop fully fledged mobile phone banking in Malawi and it is the Telecommunication Network Operators (TMOs) that are providing mobile money services instead.

POS devised are at an adoption stage as well where only one bank is providing such banking access devices in a limited number of supermarkets and shops. Usage of POS devices is limited because not many banks in Malawi offer debit and/or credit cards but ATM cards which cannot be used in POS devices. The trend in Malawi however is in line with findings of Goode and Moutinho (1995) that there is a growing preference to self service technological interfaces 
that enable customers to enjoy a service independent of direct service employee involvement and ATMs are now the second most popular access channel to banking products/services in Malawi (Mwatsika, 2014) while the other channels are worthy exploring and expanding. As the number of banks grows in Malawi the competition is growing among the banks to keep customers satisfied and thereby retain an expanding base of customers and remain profitable.

\subsection{Customer Satisfaction}

The concept of customer satisfaction has various definitions generated by empirical researchers. Westbrook and Oliver (1981) has one of the commonly used definition of customer satisfaction which asserts that customer satisfaction is a mental state which results from customers' comparison of expectations prior to a purchase with the performance perceptions after a purchase. The comparison is transaction specific (Halstead et al, 1994) and Day (1984) refer to it as an evaluative judgment concerning a specific purchase selection whether it met the customers' expectations or not.

What is common in definitions of customer satisfaction by Westbrook and Oliver (1981), Day (1984), Halstead et al (1994), Cadotte et al (1987) and Churchill and Surprenant (1982) among other empirical researchers is that, customer satisfaction is considered a response, emotional or cognitive pertaining to particular focus, either expectations about a product or consumption experience which occurs at a particular time and is based on customers' accumulated experience.

Customer satisfaction with ATM banking therefore is a response to the use experience of ATM banking which occurs at a particular time and is based on customers' accumulated experience of ATM banking services from their respective banks whereas the customer satisfaction with banks can be regarded as a culmination of banking experience enjoyed over time whether it meets expectations or not.

With regards to evaluation of particular ATM usage experience, studies have found that customers are satisfied with ATM banking in Malawi (Mwatsika, 2014), Pakistan (Khan, 2010), India (Komal, 2009) and Malaysia (Kheng, et al, (2010). However, not many studies have looked into whether satisfaction with ATM banking performance translates into satisfaction with the bank. Achieving customer satisfaction is of particular importance because empirical studies have shown that customer satisfaction is an antecedent of customer retention (Newman, 2001; Rust et al, 1994) which gives an organisation increased sales (Levesque and McDougall, 1996) market share and improved corporate image (Newman, 2001). Therefore deployment of ATMs is expected to contribute towards the concept of customer satisfaction with banks.

\subsection{Measuring Customer Satisfaction}

Customer satisfaction is one of the frequently researched concepts in marketing. At the centre of understanding customer satisfaction is the concept of service quality.
Although there are no commonly accepted definitions of both concepts of customer satisfaction and service quality; service quality is defined as a measure of how well a service delivered matches the customers' expectations (Lewis and Booms, 1983). It is said that service quality is best defined by the consumer of the service thereby making it subjective in the sense that two persons could perceive service quality delivered differently.

Literature posits that service quality is an attitude of overall judgment about service superiority. The judgment that is obtained from comparing performance perceptions with expectations (Parasuraman et al, 1988) or performance alone (Cronin and Taylor, 1992). It is based on this judgment that customers perceive satisfaction with the service. Customers perceptions are beliefs about the experienced service (Sachdev and Verma, 2004) and expectations are beliefs about a service having the desired attributes (Parasuraman et al, 1985) and that expectations are used as a standard to service evaluation. Service quality therefore is an antecedent of customer satisfaction (Anderson and Sullivan, 1993; Anderson and Fornell, 1994) highlighting the importance of service quality in influencing customer satisfaction and customer behaviour towards brand loyalty, repeat purchases and willingness to recommend (Levesque and McDougall, 1996; Magi and Julander, 1996).

Measurement of customer satisfaction has been dominated by the performance disconfirmation paradigms. However, Seth et al (2005) provide a review of nineteen service quality models that can be used to measure customer satisfaction with a product/service and these include: Technical and functional quality model by Gronroos (1984); GAP model Parasuraman et al (1985); Attribute service quality model Haywood-Farmer (1988); Synthesis model of service quality - Brogowicz et al (1990); Performance only model - Cronin and Taylor (1992); Ideal value model of service quality Mattson (1992); Evaluated performance and normed quality model - Teas (1993); IT alignment model - Berkley and Gupta (1994); Attribute and overall effect model - Dabholkar (1996); Model of perceived service quality and satisfaction Spreng and Mackoy (1996); PCP attribute model - Philip and Hazlett (1997); Retail service quality and perceived value model - Sweeney et al (1997); Service quality customer value and customer satisfaction model - Oh (1999); Antecedents and mediator model - Dabholkar et al (2000); and Internal service quality model - Frost and Kumer (2000).

The popular approaches to measuring customer satisfaction however are; first, the importance - performance model by Fishbein and Ajzen (1975) which proposes that a customer's satisfaction with a product or service is a composite of (1) the perceived importance attached to the range of the product/service attributes or benefits and (2) the customer's beliefs about the degree to which the product/service has each attribute. When a product/service is perceived to have and performs in the attributes customers perceive important, it is expected that customers will be satisfied. Secondly, the expectations-performance paradigm by Parasuraman et al (1985) on the other hand states that a 
customer is satisfied with a product/service if the product/service performance meets or exceeds the customer's expected performance of the product/service. The model is based on GAP analysis (Parasuraman et al, 1985) in the conceptualization and delivery of the service quality. The researchers (Parasuraman et al, 1985) visualize the existence of service quality gaps. The first gap is the difference between customers' expectations and management's perceptions of customer's expectations, that is, not knowing precisely what the customer expects. The second gap is the difference between management's perceptions of customer's expectations and the service quality specifications drawn to guide the service delivery, that is, improper service quality standards. The third gap is the difference between service quality specifications and the actual service delivered to the customer that is the service quality gap. The fourth gap is the difference between the service delivery and the external communication to the customer about the service delivered, that is, matching service delivery and promises. The last (fifth) gap is the difference between customer's expectations of the service and the perceptions of the service delivered. This last gap forms the perceptions of service quality in the customer, therefore service quality becomes a function of perceptions and expectations.

Based on the GAP analysis (Parasuraman et al, 1985), Parasuraman et al (1988) developed a customer satisfaction measurement framework popularly known as SERVQUAL. SERVQUAL is a multi-dimension and multi-attribute measurement scale where customers rate a product/service on a set of general attributes on a Likert type scale. Parasuraman et al (1988) identified ten service quality dimensions which were later collapsed into five service quality dimensions of tangibles, reliability, responsiveness, assurance and empathy with 22 general service quality attributes. SERVQUAL has been widely used in service quality and customer satisfaction studies across industries (Aldlaigan and Buttle, 2002; Andaleeb and Basu, 1994; Asubonteng et al, 1996; Babakus and Boller, 1992; Boulding et al, 1993; Brown and Swarth, 1989; Ennew, et al, 1993; Yavas et al, 2004).

SERVQUAL has drawn criticism from Carman (1990) who argues that subjects should rate a product/service on criteria that are relevant to the specific product/service supporting empirical researchers who argue that the general attributes have potential to carry in-built bias towards dissatisfaction since expectations are determined by the ideal product/service. Nonetheless SERVQUAL (Parasuraman et al, 1988) is one of the popular measurement models of customer satisfaction which has been used in various studies (Fick and Ritchie, 1991) and remains one of the popular service quality measurement models.

Cronin and Taylor (1992) eliminated the element of expectations from Parasuraman et al (1988) SERVQUAL model to perceive that service quality and customer satisfaction is a form of attitude that performance only is an enhanced means of measurement. This led to the development of SERVPERF model which uses the same multi-dimension and multi-attribute scale as SERVQUAL but service quality is evaluated by measuring performance only without expectations (Parasuraman et al, 1988) or importance weights (Fishbein and Ajzen, 1975) being used as a standard of comparison. Several researchers (Bolton and Drew, 1991; Boulding et al, 1993, Gotlieb et al, 1994) agree that assessment of service quality and customer satisfaction may depend solely on performance and that SERVPERF may have less bias than SERVQUAL in measuring service quality (Cronin and Taylor, 1992).

\section{Results and Discussion}

Respondents to the study were from five commercial banks in Malawi namely; Financial Discount House (FDH) Bank, Malawi Savings Bank (MSB), New Building Society (NBS) Bank, Standard Bank and National Bank of Malawi (NBM). All respondents have been with their respective banks for a period of over two years and 87.2 percent of the respondents use ATM banking at least every week.

The study received 71 percent of the responses from the targeted study sample where 40.6 percent of the responses were from female respondents and 59.4 percent from male respondents. The majority of the respondents ( 81.3 percent) were aged between 26 and 45 years and 71.9 percent had graduate to postgraduate qualifications while 28.1 percent were undergraduates. The number of responses was not proportional per bank as there were 11 respondents from FDH Bank, 11 from MSB, 33 from NBS Bank, 88 from Standard Bank and 209 from NBM and neither this is an indication of the banks market penetration.

Table 1. Regression analysis of ATM Attributes and Customer Satisfaction with ATM Banking.

\begin{tabular}{|c|c|c|c|c|c|c|c|c|c|}
\hline \multicolumn{10}{|c|}{ Model Summary } \\
\hline \multirow{2}{*}{ Model } & \multirow{2}{*}{$\mathbf{R}$} & \multirow{2}{*}{ R Square } & \multirow{2}{*}{$\begin{array}{l}\text { Adjusted } \\
\text { R Square }\end{array}$} & \multirow{2}{*}{$\begin{array}{l}\text { Std. Error of } \\
\text { the Estimate }\end{array}$} & \multicolumn{5}{|l|}{ Change Statistics } \\
\hline & & & & & R Square Change & F Change & df1 & df2 & Sig. F Change \\
\hline 1 & $1.000^{\mathrm{a}}$ & 1.000 & 1.000 & .000 & 1.000 & $5.706 \mathrm{E} 15$ & 23 & 306 & .000 \\
\hline
\end{tabular}

a. Predictors: (Constant), ATM Fees charged, Appearance of corporate branding on ATM, Employee Friendliness, Issuing of Clean Notes, Waiting times on ATM, Quick replacement of lost ATM cards, Security and advise on ATM usage, Cash availability in ATMs, Service range at ATMs, Easy application process for ATM cards, User friendliness of ATM systems, Security at ATM, Readable ATM Slips, Convenient Location, Employee access, Fast return of swallowed ATM cards, Cleanliness of ATMs, Accuracy of ATM transactions, Employee Speed, Privacy at ATMs, Easy access to ATM, Speed of ATMs, Employee effectiveness. 
It is important to note first that the attributes that were adapted to measure customer satisfaction with ATM banking provided a perfect model (Table 1) where the R square of 1.000 denotes that all the attributes adopted provided 100 percent predictive capability of satisfaction with ATM banking with statistical significance $\mathrm{p}<0.001$.

Table 2 shows frequencies of respondents rating of their satisfaction with ATM banking and Table 3 shows frequencies of respondents rating of their overall satisfaction with their respective banks both on a Likert scale of 1 to 5 where 1 was equal to 'very poor', 'very dissatisfied'; 2 was equal to 'poor', 'dissatisfied'; 3 was equal to 'neither poor nor good', 'neither dissatisfied not satisfied'; 4 was equal to 'good', 'satisfied' and 5 was equal to 'very good', 'very satisfied'.

Table 2. Customer satisfaction with ATM banking.

\begin{tabular}{llllll}
\hline \multicolumn{7}{l}{ Satisfaction Ratings } \\
\hline Bank & $\mathbf{2}$ & $\mathbf{3}$ & $\mathbf{4}$ & $\mathbf{5}$ & Total \\
\hline FDH Bank & 0 & 0 & 11 & 0 & 11 \\
MSB & 0 & 0 & 11 & 0 & 11 \\
NBM & 77 & 33 & 55 & 44 & 209 \\
NBS & 33 & 0 & 0 & 0 & 33 \\
Standard Bank & 11 & 22 & 55 & 0 & 88 \\
TOTAL & & & & & 352 \\
\hline
\end{tabular}

Source: Descriptive Analysis, SPSS

Table 3. Customer satisfaction with Bank.

\begin{tabular}{llllll}
\hline \multicolumn{7}{c}{ Satisfaction Ratings } \\
\hline Bank & $\mathbf{2}$ & $\mathbf{3}$ & $\mathbf{4}$ & $\mathbf{5}$ & Total \\
\hline FDH Bank & 0 & 11 & 0 & 0 & 11 \\
MSB & 11 & 0 & 0 & 0 & 11 \\
NBM & 77 & 33 & 77 & 22 & 209 \\
NBS & 11 & 11 & 11 & 0 & 33 \\
Standard Bank & 22 & 33 & 33 & 0 & 88 \\
TOTAL & & & & & 352 \\
\hline
\end{tabular}

Source: Descriptive Analysis, SPSS

Although all respondents from FDH Bank were satisfied with the performance of the ATM banking from their bank (Table 2), but all the respondents were neither dissatisfied nor satisfied with their bank overall (Table 3). The respondents from MSB were satisfied with the ATM banking from their bank and all of them were dissatisfied with their bank overall (Table 3). NBM had 47 percent of its respondents satisfied with its ATM banking, 16 percent neither dissatisfied nor satisfied and 37 percent dissatisfied with its ATM banking. Equally the same percentages of respondents from NBM were overall dissatisfied and satisfied with the NBM. For NBS all respondents were not satisfied with its ATM banking (Table 2), however 33 percent of the respondents were overall satisfied with their bank (Table 3). For Standard Bank 55 respondents were satisfied with their bank's ATM banking (Table 3), 22 were neither dissatisfied nor satisfied and 11 were dissatisfied (Table 2). 33 respondents were overall satisfied with their bank, 33 were neither dissatisfied nor satisfied and 22 were dissatisfied with their bank (Table 3 ).

The study results are interesting because although most respondents from FDH, MSB and Standard Bank were satisfied with ATM banking offered by their respective banks, they were not equally satisfied with their bank. Whereas all the respondents from NBS were not satisfied with the ATM banking from their bank, 33 percent of the respondents were still satisfied with their bank. It is a very unusual case with NBM where the same frequencies of responses apply to both satisfaction with ATM banking and the bank.

The data was therefore subjected to linear regression analysis to assess the predictive power of satisfaction with ATM banking performance on the satisfaction with the bank. Table 4 is the model summary of the regression analysis of satisfaction with ATM banking (independent variable) and satisfaction with bank (dependent variable). The adjusted $\mathrm{R}$ square of 0.403 denotes that satisfaction with ATM banking explains 40 percent of customers' satisfaction with their respective banks with statistical significance $p<0.001$.

This result demonstrates that ATM banking performance is one of the key elements that determine satisfaction with banks in Malawi. ATM banking is the second popular access channel to banking products/services behind branch banking and this study further confirms the importance of ATM banking in determining customer satisfaction with banks.

Table 4. Regression analysis: Satisfaction with ATM banking and satisfaction with bank.

\begin{tabular}{|c|c|c|c|c|c|c|c|c|c|}
\hline \multicolumn{10}{|c|}{ Model Summary } \\
\hline \multirow{2}{*}{ Model } & \multirow{2}{*}{$\mathbf{R}$} & \multirow{2}{*}{ R Square } & \multirow{2}{*}{$\begin{array}{l}\text { Adjusted } \\
\text { R Square }\end{array}$} & \multirow{2}{*}{ Std. Error of the Estimate } & \multicolumn{5}{|l|}{ Change Statistics } \\
\hline & & & & & R Square Change & F Change & df1 & df2 & Sig. F Change \\
\hline 1 & $.636^{\mathrm{a}}$ & .405 & .403 & .743 & .405 & 238.286 & 1 & 350 & .000 \\
\hline
\end{tabular}

a. Predictors: (Constant), Satisfaction with ATM Banking

Source: Regression Analysis, SPSS

Based on these results, banks need to consider ATM banking a significant area of customer service provision in the quest to achieve greater customer satisfaction with the bank itself in order to expand the base of satisfied customers. There are however other elements in the customer satisfaction equation with the bank that make up the other 60 percent which require further studies so that adequate knowledge is generated on factors that contribute to 100 percent customer satisfaction with banks. The study findings nonetheless support the research hypothesis that ATM banking performance has a positive and statistically significant relationship with customer satisfaction with banks.

To condense further the importance of ATM banking in the customer satisfaction equation, respondents were asked if 
they would consider switching banks because of poor ATM banking performance. 75 percent of the respondents indicated that they are unlikely to change banks because of poor ATM banking service against 19.1 percent who were certain about changing banks because of poor ATM banking service. Respondents were further asked whether they would recommend their bank irrespective of poor or good performance of ATM banking. 81.3 percent of the respondents indicated that they were likely to recommend their respective banks irrespective of the performance of ATM banking.

These responses point to the fact that much as ATM banking is key in providing customer satisfaction with banks, it is not adequate to lure customers from other banks since customers cannot switch banks due to poor ATM banking performance. Customers would not be attracted to join a bank because of newer efficient ATM technologies. ATM banking is not adequate for attracting new customers from other banks although it plays a significant role in determining customer satisfaction with the banks.

Johnston (1995) noted that differences in education, culture, experience, and tolerance levels of service quality affect participants' perceptions of satisfaction in particular contexts, it would be interesting based on these findings to replicate this study in different contexts to further understand the effects of satisfaction with ATM banking performance on customer satisfaction with bank. It would also be necessary to investigate the other key elements that affect customer satisfaction with banks apart from ATM banking focusing on factors that would attract customers to switch banks as that knowledge would be ideal in developing competitive strategies to achieve larger customer bases and profitability with banks.

\section{Conclusion}

In this study 352 responses were involved in the assessment of the impact of ATM banking performance on customer satisfaction with banks. The study was a regression analysis where participants rated their perceptions on the performance and satisfaction with ATM banking on a multidimension and multi-attribute measurement scale. The attributes were specific to ATM banking and were adopted from empirical researches. A regression analysis was then conducted between satisfaction with ATM banking and satisfaction with the bank.

The results of the analysis have found that satisfaction with ATM banking explains 40 percent of customer satisfaction with the bank in other words ATM banking has 40 percent predictive capability of customer satisfaction with the bank. This result condenses the importance of ATM banking behind branch banking. However follow up questions on the respondents' likelihood to switch banks due to poor ATM banking and the prospect of recommending their bank on the basis of ATM banking performance show the weakness of ATM banking in attracting customers to switch banks. The study found that the majority of the respondents would not switch banks despite poor ATM banking and would still recommend their bank despite poor ATM banking.

The results first supported the research hypothesis that ATM banking has a positive relationship with satisfaction with bank by finding that the relationship is indeed positive and statistically significant. However, the results reveal that investment in ATM banking would only be ideal for improvement in bank customer satisfaction but strategies to lure customers from rival banks to switch banks should come from other strategic marketing alternatives.

\section{References}

[1] Aldlaigan, A., and Buttle, A. (2002). SYSTRA-SQ: a new measure of banks service quality. International Journal of Service Industry Management. 13(4), pp. 362-381.

[2] Al-Hawari, M. and Ward, T. (2006). The impact of automated service quality on financial performance and the mediating role of customer retention. Journal of Financial Service Marketing. 10(3), pp. 228-43.

[3] Andaleeb, S. S. and Basu, A. K. (1994). Technical complexity and consumer knowledge as moderators of service quality evaluations in the automobile service industry. Journal of Retailing Vol. 70(4) pp367-379.

[4] Anderson, E., \& Sullivan, M. (1993). The antecedents and consequences of customer's satisfaction for firms. Marketing Science, 12(2), 125-143.

[5] Anderson, E. W. and Fornell, C. (1994). A customer satisfaction research prospectus. Services marketing: new directions in theory and practice. Thousand Oaks, CA: Sage Publications, pp. 241-68.

[6] Asubonteng, P., McCleary, K. J. and Swan, J. E. (1996). SERVQUAL revisited: a critical review of service quality. Journal of Service Marketing 10(6): 62-81.

[7] Athanassopoulos, A. (2000). Customer satisfaction cues to support market segmentation and explain switching behaviour. Journal of Business Research. 47(3), pp.191-207.

[8] Babakus, E. and Boller, G. W. (1992), "An empirical assessment of the SERVQUAL scale", Journal of Business Research, Vol. 26 No. 6, pp. 253-268.

[9] Banker, R. D. and Kauffman, R. J. (1988). Strategic contributions of information technology: An empirical study of ATM networks, proceedings of the ninth International Conference for Information Systems, Minneapolis, MW.

[10] Berkley, B. J. and Gupta, A. (1994). Improving service quality with information technology, International Journal of Information Management, Vol. 14, pp. 109-21.

[11] Bolton, R. N. and Drew, J. H. (1991). A multistage model of customers' assessment of service quality and value, Journal of Consumer Research, Vol. 17, March, pp. 375-84.

[12] Boulding, W., Kalra, A., Staelin, R. and Zeithmal, V. A. (1993). A dynamic process model of service quality: from expectations to behavioural intentions. Journal of Marketing Research Vol.30 pp 7-27. 
[13] Brogowicz, A. A., Delene, L. M. and Lyth, D. M. (1990). A synthesized service quality model with managerial implications. International Journal of Service Industry Management. 1(1), pp. 27-46.

[14] Brown, S. W. and Swarth, T. A. (1989). A gap analysis of professional service quality. Journal of Marketing Vol. 53, pp 92-98.

[15] Cadotte, E. R., Woodruff, R. B. and Jenkins, R. L. (1987). Expectations and norms in models of consumer satisfaction. Journal of Marketing Research. 24 (August): pp. 305-314.

[16] Carman, J. M. (1990). Consumer Perception of Service Quality: An Assessment of the SERVQUAL Dimensions. Journal of Retailing. 66, pp. 33-55.

[17] Churchill, G. A. and Surprenant, C. (1982). An investigation into the determinants of customer satisfaction. Journal of Marketing Research, Vol. 19, pp. 491-504.

[18] Cronin, J. J. and Taylor, S. A. (1992). Measuring service quality: A reexamination and extension. Journal of Marketing, 56, July, pp. 55-68.

[19] Dabholkar, P. A. (1996). Consumer evaluations of new technology-based self-service operations: an investigation of alternative models, International Journal of Research in Marketing, Vol. 13 No. 1, pp. 29-51.

[20] Dabholkar, P. A., Shepherd, C. D. and Thorpe, D. I. (2000), "A comprehensive framework for service quality: an investigation of critical conceptual and measurement issues through a longitudinal study", Journal of Retailing, Vol. 76 No. 2, pp. 131-139.

[21] Davies, F., Moutinho, L. and Curry, B. (1996). ATM users attitudes: A neural network analysis. Marketing intelligence \& Planning, 14(2), 26-32.

[22] Day, R. L. (1984). Modeling choices among alternative responses to dissatisfaction. In Advances in Consumer Research $11^{\text {th }}$ Ed. William D. Perreault. Atlanta, GA: Association for Consumer Research, pp. 496-499.

[23] Dos Santos, B. L. and Peffers, K. (1993). The effects of early adoption of information technology: An empirical study. Journal of Information Technology Management. Vol. 5(1) 1-13.

[24] Ennew C. T, Reed GV, and Binks M. R. (1993), "Importance performance analysis and the measurement of service quality", European Journal of Marketing Vol. 27(2): pp.59-70.

[25] Fick, G. R. and Ritchie, J. R. B. (1991). Measuring service quality in the travel and tourism Industry. Journal of Travel Research, Vol. 30 No. 2, pp. 2-9.

[26] Fishbein, M. and Ajzen, I. (1975). Belief, attitude, intention and behavior: An introductionto theory and research. Addison-Wesley, Reading, Massachusetts.

[27] Frost, F. A. and Kumar, M. (2000). INTSERVQUAL: an internal adaptation of the GAP model in a large service organization, Journal of Services Marketing, Vol. 14 No. 5, pp. 358-77.

[28] Glaser, P. F. (1988). Using technology for competitive advantage: the ATM experience of Citicorp in managing innovation cases from services industries. Guide, B. R. and Quinn, J. B. (eds) National Academy Press, Washington DC pp 108-114.
[29] Goode, M. and Moutinho, L. (1995). The effects of free banking on overall satisfaction: the use of automated teller machines. International Journal of Bank Marketing. Vol. 13(4) 168-190.

[30] Gotlieb, J. B., Grewal, D. and Brown, S. W. (1994). Consumer satisfaction and perceived quality: complementary or divergent constructs? Journal of Applied Psychology, Vol. 79 No. 6, pp. 875-85.

[31] Gronroos, C. (1984). A service quality model and its marketing implications. European Journal of Marketing. 18(4), pp. 36-44.

[32] Halstead, D., David H., and Sandra L. S. (1994). Multisource effects on the satisfaction formation process. Journal of the Academy of Marketing Science, 22 (Spring): 114-129.

[33] Haywood-Farmer, J. (1988). A conceptual model of service quality. International Journal of Operations \& Production Management. 8(6), pp. 19-29.

[34] Howcroft, J. B. (1991). Customer satisfaction in retail banking. Service Industry Journal, January, pp. 11-17.

[35] Johnston, R. (1995). The zone of tolerance: exploring the relationship between service transactions and satisfaction with the overall service. International Journal of Service Industry Management, 6(2), pp. 46-61.

[36] Joseph, M. and Stone, G. (2003). An empirical evaluation of US bank customer perceptions of the impact of technology on service delivery in the banking sector. International Journal of Retail \& Distribution Management, 31(4), pp. 190-202.

[37] Kantrow, Y. D. (1989). ATMs called 'only hope' to minimize costs, cope with shrinking labour force. American Banker.

[38] Khan, A. M. (2010) An empirical study of ATM service quality and customer satisfaction in Pakistani banks. European Journal of Social Sciences. Vol.13 (3) 333-344.

[39] Kheng, L. L., Mahamad, O., Ramayah, T. (2010) The impact of service quality on customer loyalty: A study of banks in Penang, Malaysia. International Journal of Marketing Studies. Vol.2 (2) 57-66.

[40] Komal, S. S. (2009) Impact of ATM on customer satisfaction (A comparative study of SBI, ICICI and HDFC banks). Business Intelligence Journal Vol. 2(2) 276-287.

[41] Laderman, F. S. (1990). The public policy implications of state laws pertaining to Automated Teller Machines. Economic Review (Federal Reserve Bank of San Francisco pp. 43-58.

[42] Levesque, T. J., and McDougall, G. H. G. (1996). Determinants of customer satisfaction in retail banking. International Journal of Bank Marketing. 14(7), pp. 12-20.

[43] Lewis, R. C. and Booms, B. H. (1983). The marketing aspects of service quality. Emerging perspectives in service marketing, In Berry, L. L., Shostack, G. and Upah, G. (eds.) American Marketing Association. Chicago, IL pp. 99-107.

[44] Magi, A. and Julander, C. R. (1996). Perceived service quality and customer satisfaction in a store performance framework: An empirical study of Swedish Grocery Retailers. Journal of Retailing and Consumer Services, Vol. 3(1) pp 33-41.

[45] Mattson, J. (1992). A service quality model based on ideal value standard, International Journal of Service Industry Management, Vol. 3 No. 3, pp. 18-33. 
[46] Moutinho, L. and Brownlie, D. T. (1989). Customer satisfaction with bank services: a multidimensional space analysis. International Journal of Bank Marketing, 7(5), pp. 23-27.

[47] Mwatsika, C. (2014). Customers' satisfaction with ATM banking in Malawi. African Journal of Business Management. Vol. 8 (7) 218-227

[48] Newman, K. (2001). Interrogating SERVQUAL: A critical assessment of service quality measurement in a high street retail bank. International Journal of Bank Marketing, 19(3), pp. 126-139.

[49] Nunnally, J. C. and Bernstein, I. H. (1994). Psychometric Theory, 3rd ed., McGraw-Hill, New York, NY.

[50] Oh, H. (1999). Service quality, customer satisfaction and customer value: a holistic perspective", International Journal of Hospitality Management, Vol. 18, pp. 67-82.

[51] Parasuraman, A., Zeithaml, V. A. and Berry, L. L. (1985). A conceptual model of service quality and implications for future research. Journal of Marketing.49, Fall, pp. 41-50.

[52] Parasuraman, A., Zeithaml, V. A. and Berry, L. L. (1988). SERVQUAL: A multiple-item scale for measuring consumer perceptions of service quality. Journal of Retailing, Spring, pp. 12-40.

[53] Patri'cio, L., Fisk, R. P. and Cunha, J. F. (2003). Improving satisfaction with bank service offerings. Managing Service Quality, 13 (6), 471-482.

[54] Philip, G. and Hazlett, S. A. (1997), "The measurement of service quality: a new P-C-P attributes model", International Journal of Quality \& Reliability Management, Vol. 14 No. 3, pp. 260-286.
[55] Rust, R. T. and Oliver, R. L. (1994). Service quality insights and managerial implications from the frontier in Roland $\mathrm{T}$. Rust and Richard L. Oliver (eds), Service Quality: New Dimensions in Theory and Practice, Thousand Oaks, CA: Sage Publications pp $1-9$.

[56] Sachdev, S. B. and Verma, H. V. (2004). Relative importance of service quality dimensions: A multi-sectoral study. Journal of Services Research, Vol. 4(1).

[57] Seth, N. S., Deshmukh, S. G., and Vrat, P. (2005). Service quality models: a review. International Journal of Quality \& Reliability Management. 22(9), pp. 913-949.

[58] Spreng, R. A. and Mackoy, R. D. (1996). An empirical examination of a model of perceived service quality and satisfaction, Journal of retailing, Vol. 722, pp. 201-14.

[59] Sweeney, J. C., Soutar, G. N. and Johnson, L. W. (1997). Retail service quality and perceived value, Journal of Consumer Services, Vol. 4 No. 1, pp. 39-48.

[60] Teas RK (1993). Expectation, performance evaluation and consumer's perceptions of quality. Journal of Marketing, Vol. 57 (4), pp. 18-34.

[61] Westbrook, R. A., and Oliver, R. L. (1981). Developing better measures of consumer satisfaction: some preliminary results. pp. 94-99 In Advances in Consumer Research, Vol. 8. Ed. Kent Monroe.

[62] Yavas, U., Benkenstein, M. and Stuhldreier, U. (2004). Relationship between service quality and behavioural outcomes: A study of private bank customers in Germany. The International Journal of Bank Marketing, 22(2/3), 144-157. 